Dr Željko Fajfrić

advokat u Šidu

\title{
JOVAN MUŠKATIROVIĆ*
}

\section{a) Rođenje}

Jovan Muškatirović je rođen u Senti 1743. godine. ${ }^{1}$ Sama godina njegovog rođenja i nije tako sigurna i daje se tek okvirno. ${ }^{2}$ Jovan Grčić je svojevremeno navodio da je Muškatirović rođen 1763 . godine. ${ }^{3}$ Čini se da je Safarikov podatak tačniji, jer sam Muškatirović u predgovoru jedne svoje knjige koja je izdana 1807. godine (sam predgovor je pisan maja meseca 1806. godine) $)^{4}$ navodi da se nalazi „u sedmom desetoletiju života". $\mathrm{Na}$ istome mestu Muškatirović navodi da mu se otac zvao Lazar: „Ovo je dražajšeg roditelja mojego Lazara Muškatirovića svjati meni sovjet bio..."s

Sudeći po prezimenu (Muškatirović) potiče iz porodice u kojoj su vojne tradicije bile veoma stare i jake. Verovatno da je neki od predaka ove porodice služio u srpskim krajevima Ugarske u redovnoj vojsci (mušketirima) pa je odatle izvučeno i ovo prezime.

Inače, u specifikaciji potiskih graničara koji se 1751. godine nisu želeli da isele u kasniji Velikokikindski distrikt, ali ni u Rusiju, već su ostali u Bačkoj, navode se kapetan Đorđe Golub, poručnik Jovan Badrljica i senator Lazar Muškatirov. ${ }^{6}$ Ne zna se da li je taj Lazar Muškatirov otac Jovana Muškatirovića ili. su oni tek iz iste porodice. U svakom slučaju,

* Rad primljen: 26. III 2001.

I P. J. Safarik. Geschichte des serbischen Schrifthums. Prag 1865, str. 322.

2 Ovde jedna napomena. O Jovanu Muškatiroviću iz crkvenih protokola se ne može ništa saznati budući da su svi protokoli do 1823. godine sagoreli u Buni od 1848. godine.

3 J. Grčić, Istorija srpske književnosti, drugo izdanje, str. 94. i 343.

4 Drugo izdanje Pričta, Budim 1807.

5 Pricte, Budim 1807, II izdanje, str. 15.

6 Arhiv Karlovačke mitropolije 1752/319. 
Jovan Muškatirović potiče iz pismene i veoma kulturne porodice za ono vreme tako da njegovo školovanje i sav daljnji život ima dublje porodične korene.

Iz svega se dâ zaključiti da Muškatirovići u ta burna vremena ostaju u Bačkoj i tu se provincijalizuju kao stanovnici Potiskog distrikta.

Jovan Muškatirović je završio pravo na Univerzitetu u Pešti, a advokatski ispit je položio 1769. Bio je prvi od Srba koji je postao advokat u Ugarskoj, dakle prvi od Srba bio je „vengerskih prav advokat”?

Muškatirović je oduvek bio veoma ponosan na činjenicu da je advokat, pa se tako uvek i potpisivao na svojim knjigama: „črez slavnoje kraljevstvo Mađarskoje, i strane jemu prinadležašte zakleti advokat".

Bio je to tek početak, u narednim godinama biće još Srba advokata: „Od tada do početka XIX veka Srbi u Ugarskoj imali su već 34 pravnika, dok je prvi doktor prava bio Sava Tekelija, koji je doktorat položio u Pešti 1775. godine". ${ }^{8}$

\section{b) Kada je Jovan Muškatirović položio advokatski ispit?}

Do sada je bilo ustaljeno verovanje da je Jovan Muškatirović, prvi od Srba advokat sa položenim advokatskim ispitom u Ugarskoj, položio advokatski ispit 1773. godine: „Jovan Muškatirović, rodom iz Sente. Položio ispit 1773. i zakletvu u Budimu".9

Slično je mnogo ranije pisao i Pavle J. Safarik. On navodi da se Jovan Muškatirović rodio u Senti, da je bio ugarski advokat, da je položio advokatsku zakletvu 10. marta 1773. godine, da je bio senator u Pešti i da je umro u 66. godini života (18. jula 1809. godine). ${ }^{10}$

Tako i J. Skerlić: „Svršivši prava na peštanskom univerzitetu, položivši advokatsku zakletvu 10. marta 1773. godine, on je prvi od Srba postao advokat u Ugarskoj"."

Kod D. Popovića postoji nešto veća greška. On navodi: „Svršio je prava u Pešti i 1783. postao prvi Srbin advokat u Mađarskoj". ${ }^{2}$ Slično i Z. Milisavac: „Prvi Srbin advokat u Ugarskoj bio je Jovan Muškatirović (1773), poznat kao pisac i skupljač narodnih poslovica". ${ }^{3}$

Istu grešku ponavlja i Veljko Petrović u Narodnoj enciklopediji u natpisu o Jovanu Muškatiroviću: „O njegovu školovanju zna se samo, da je svršio prava u Pešti i da je, položivši advokatsku zakletvu 10. 3. 1783. bio prvi Srbin advokat u Ugarskoj". ${ }^{4}$

7 D. Popović, Srbi u Vojvodini, knjiga druga, Novi Sad 1990, str. 399.

8 Zे. Milisavac, Istorija Matice srpske, I deo, Novi Sad 1986, str. 17.

9 Istorija jugoslovenske advokature, I knjiga, Beograd 1998, str. 215.

10 P. J. Safarik, Geschichte des serbische Schrifthums, Prag 1865, str. 322.

11 J. Skerlić, Srpska književnost u XVIII veku, Beograd 1966, str. 375.

12 D. Popović, Srbi u Vojvodini, knjiga druga, Novi Sad 1990, str. 410.

13 Ż. Milisavac, Istorija Matice srpske, I deo, Novi Sad 1986, str. 17.

14 S. Stanojević, Narodna enciklopedija, srpsko-hrvatsko-slovenacka, knjiga II, Zagreb 1929, str. 928/9. 
Svi oni podatak o 1773. godini, kao godini kada je Muškatirović položio advokatsku zakletvu, crpe iz Letopisa Matice srpske iz 1826. godine (tada ga je uređivao Georgije Magarašević) gde se u svesci 14. objavljuju imena Srba advokata: ,a dao je popis svih advokata - njih 227 - od Jovana Muškatirovića (1783) do Jakova Kneževića (1827), redovno sa osnovnim biografskim podacima". ${ }^{\text {s }}$ Inače, tu je navedeno ukupno 227 advokata Srba u Ugarskoj u vremenu od 1773. pa sve do 1826. godine.

Taj je podatak sasvim pogrešan. Naime, Jovan Muškatirović se još od početka 1769. godine u novosadskom magistratu navodi kao advokat. Dana 21. januara 1769. godine Ostoja Nićiforović (senator Potiskog distrikta) izlazi pred Davida Rackovića (sudija Novoga Sada) i ovlašćuje advokata Jovana Muškatirovića da ga zastupa. Inače, radi se o parnici radi naplate duga gde je Nićiforović poverilac. ${ }^{16}$ Dakle, već 1769 . godine u zvaničnim dokumentima pred sudom Jovan Muškatirović se uvodi kao advokat.

Nešto kasnije te godine (15. februara) advokat Jovan Muškatirović zastupa pred magistratom plemića Georgija Golubovića (bivšeg potporučnika). Golubović kao staralac svoje dece (od pokojne žene Ane Radonić) opunomoćuje advokata Jovana Muškatirovića da ga zastupa u svim parnicama koje je pokrenuo i koje bude pokretao.

Ovde treba napomenuti da u to vreme u Novom Sadu postoji još samo jedan advokat. Kako je taj advokat bio nesrbin, to su svi Srbi u Novom Sadu uglavnom dolazili kod Muškatirovića.

Dana 10. februara 1769. godine carica Marija Terezija izdala je uredbu kojom je regulisala pitanje advokata u Ugarskoj. Kao motivi ove regulacije navode se sporo izricanje pravde, prevelik broj advokata od kojih mnogi idu jedino za time da što više zarade, podstiču svet na nepotrebno parničenje, uzimaju previše parnica koje onda odugovlače, itd. Zbog svega toga trebalo je napraviti reda u advokaturi. Stoga advokatsku zakletvu ne može položiti više niko ko prethodno ne položi strog ispit kroz koji treba da se dokaže da ima dovoljno znanja koja se traže za advokata.

Sa ovom uredbom veoma je ograničen broj onih koj su se bavili advokaturom. No, postojala je jedna olakšavajuća okolnost. Ispit advokatski su mogli polagati, osim onih koji su dokazali da su izučili teoriju i imali praksu kod veštih pravnika, i oni koji su prava izučili, kako se navodi ,de sola praxi", ali samo onda kada podnesu uverenje svojih principala da su dosta iskusni u pravu.

Ovi ispiti su se polagali pred petočlanom komisijom (tzv. „sudskim tablama"). Ispit je propisan i za već zaklete advokate koji nemaju više od tri godine prakse, pa čak i za advokate sa više od tri godine prakse, ako se zaključi da su slabi u pravnom znanju. Spisak advokata vode županije i sudske table, a sve zbog toga da bi klijenti znali kome da se obraćaju.

15 Zे. Milisavac, Istorija Matice srpske. I deo, Novi Sad 1986, str. 146.

16 Glasnik Istoriskog drušna u Novom Sadu, sveska 30. Novi Sad 1937, str. 414/415. 
Ovo će pravilo da zahvati i Muškatirovića. On nije imao položeni ispit, a po svemu sudeći nije imao ni tri godine prakse.

Verovatno da je 1769. godine položio advokatski ispit. Dana 19. januara 1770. godine Novosadski magistrat odgovarao je u nekom dopisu kako je sproveo propisano pravilo o polaganju advokatskih ispita. U svome Izveštaju (od 19. januara 1770. godine) zaključuje da prema broju parnica u poslednje četiri godine Novi Sad ne treba više od dva advokata. Navodi se da je u gradu Kormendi Janoš, zakleti advokat, tu je još fískal grada, a tu su još i dva advokata, Bico Ignac i - Jovan Muškatirović. Dakle, u to vreme, početak 1770 . godine, on se navodi kao advokat. Iz toga se daje zaključiti da je on ispit položio tokom 1769. godine.

Muškatirović je imao izvesnih neprilika pri polaganju advokatskog ispita. Izveštaj navodi da ga je Novosadski magistrat uputio da položi ispit kod Bačke županije, ali ova ga je odbila uz obrazloženje da ona nije upućena, odnosno, da ne zna za regulaciju. Stoga upućuje Muškatirovića u Peštu da tamo položi ispit. Tamo je on ispit i položio.

No, sve to još uvek nije značilo da Muškatirović može ostati u Novom Sadu. Kako je zaključeno da gradu treba dva advokata, a tada ih je (sa Muškatirovićem) tamo bilo četiri, to Novosadski magistrat dozvoljava Muškatiroviću da završi započete parnice, ali mu nije dozvolio da uzme nove, osim tzv. „sumarnih” koje se rešavaju po kratkom postupku.

Ipak, Muškatirović se održao u Novom Sadu. Dana 14. marta 1770. godine on izlazi pred sud kao advokat, 26. septembra 1770. godine opunomoćio ga je Nikola Duka, pradeda po materi Zmajeve Ruže (i budući tast Muškatirovića).

\section{c) Zastupanje fruškogorskih manastira}

Pravi uspon Muškatirovića dolazi kada 1771. godine postaje advokat fruškogorskih manastira. O tome je svojevremeno pronađena u arhivi Muške gimnazije u Novom Sadu kopija ugovora. ${ }^{17}$ Iz ovoga ugovora se vidi da je 3. januara 1771. godine sklopljen ugovor između advokata Jovana Muškatirovića i mitropolita Jovana Georgijevića, šišatovačkog arhimandrita Vićentija Popovića, krušedolskog arhimandrita Pahomija i hopovskog igumana Sofronija Radojevića (s druge strane).

Sam ugovor je sastavljen iz 8 tačaka i odnosi se na manastire Krušedol, Remetu, Hopovo, Vrdnik, Jazak, Bešenovo, Šišatovac, Kuveždin, Privinu Glavu, Beočin, Rakovac i Grgeteg. Ugovorom je obuhvaćen spahiluk Dalj u Virovitičkoj i Neradin u Sremskoj varmeđi. ${ }^{18}$

Ovim ugovorom Muškatirović se obavezao da će svoju dužnost u svim slučajevima vršiti svesrdno i neumorno. S druge strane, manastiri

17 Objavljena u Glasniku Isłoriskog društva u Novom Sadu, knjiga III, sveska 1. Novi Sad 1930, str. 9-11.

18 Ovaj je ugovor objavljen u Glasniku Istoriskog drušrva u Novom Sadu, III, 1930. str. $109 / 110$. 
izjavljuju želju da on tu dužnost zadrži do kraja života, odnosno, dok to bude želeo ili dok bude svoju dužnost na manastirsko zadovoljstvo vršio.

Cena Muškatirovićevog rada je hiljadu forinti godišnje (tri stotine od mitropolita i sedam stotina od navedenih manastira). Sa ovim honorarom Muškatirović je mogao gospodski živeti, pa makar ništa drugo i ne radio osim zastupao fruškogorske manastire.

Ta zastupanja su se odnosila na odbranu srpskih privilegija kod gradanskih i vojnih vlasti u Beču. Tako se zna da je u avgustu 1778. godine boravio u manastiru Vrdniku, a avgusta 1779. godine u Novom Sadu, a sve u vezi poslova oko manastira.

Sveukupno Muškatirović više nije imao potrebe da izlazi na sud kao zastupnik privatnih parničara. Ipak, mada ređe, on ima i takvih zastupanja pred sudom. Radi se o krupnijim, po svemu sudeći i veoma unosnim, parnicama. Dana 25. maja 1773. godine zastupa bečke grosiste Bouvard \& Gaillard protiv Sergija Melik Cenazi. Dana 18. maja 1776. godine zastupa trgovca Doblera iz Graca - radi se o njihovom potraživanju protiv trgovca Konstantina Dejanovića.

\section{d) Porodični život}

Nekako tada se i oženio (ne zna se tačna godina). Supruga mu je bila Nedeljković Ekatarina (rođena 10. januara 1755. godine). Muškatirovićeva izabranica imala je tek pet godina kada je ostala bez oca - trgovca Stojana Nedeljkovića. Kako je Stojan Nedeljković umro bez testamenta, magistrat je sam raspravio njegovu ostavinu, a što znači da je određeno koliko se ima potrošiti na sahranu, itd. Na kraju je (27. aprila 1760. godine) utvrđeno da je čista ostavina, nakon odbitka svih troškova, ukupno 1400 forinti. Inače, u ovom poslu (utvrđivanja ostavine) učestvovali su i ortaci pokojnog Stojana Nedeljkovića - Marko Apostolović, Antonije Rajić i Manojlo Veselinović.

Sveukupno Ekatarinino nasledstvo dato je ovim ortacima pod interes, a onda je nasledstvo (opet pod interes) uzeo Nikola Duka. Zapravo, Duka je obećao da će Ekatarinu besplatno izdržavati, ito samo za interes od 1400 forinti. Upravo će oko ovoga da izbije sukob između Duke i Jovana Muškatirovića.

Tokom 1772. godine u Muškatirovićevom braku rodio se sin Petar. Sudeći po ovome, Ekatarina je imala u vreme rođenja sina tek 17 godina, što nadalje znači da je u vreme udaje morala imati 15 ili 16 godina. Kasnije će se roditi sin Aleksandar (29. juli 1790. godine), onda sin Simenon (rođen 3. novembra 1793. godine) i na kraju ćerke Jelisaveta i Pulherija.

Ne zna se tačno gde je tih prvih godina svoga advokatisanja (od 1769. godine) Muškatirović boravio. Po svemu sudeći razmišljanja Vase Stajića bi bila najbliža istini: „Mislimo da je Muškatirović otpočetka 
1769. stalno boravio u Novom Sadu, odlazeći iz Novog Sada samo zbog advokatskih, naročito fiskalnih poslova". ${ }^{19}$

Dakle, Muškatirović verovatno živi i radi u Novom Sadu, a što se posredno može izvući iz toga što 11. marta 1772. godine Pavle Nenadović, sekretar srpskog naroda, moli magistrat da u kuću Đorđa Nikolića uvede (umesto njega) jer nema vremena da dođe, arhiepiskopovog fiškala - Jovana Muškatirovića. Na kraju je tako i bilo, a proći će još nekoliko godina dok Muškatirović ne bude sebi kupio kuću.

Dana 2. maja 1774. godine Muškatirović je prisutan dok Dimitrije Stojićević piše testament $\mathrm{i}$ on ga (Muškatirović) potpisuje kao svedok. Njegovo se ime opet javlja 1776. godine u izveštaju o usevima u Novom Sadu i tu se navodi kako je gradu platio 22 krstine ječma na ime devetka. Možemo da pretpostavimo da je Muškatirović, čim plaća gradu, imao neku zemlju na gradskom zemljištu na kojem je imao 176 krstina ječma, a devetina je plaćana kao obaveza. ${ }^{20}$

Tokom 1777. godine (15. juli) pregledani su Dukini računi oko gospodarenja nad imovinom Ekatarine (Nedeljković) Muškatirović. U njima je tada pronađen manjak od 880 forinti, a što je Duka predstavio kao troškove Ekatarinine hrane za 11 godina dok je bila pod njegovim staranjem ( 80 forinti godišnje). No, Jovan Muškatirović je odbio da sve to prizna navodeći ,čto ona Gža Katarina, supruga jego, na svako delo od detinstva upotrebljena bivala koje i kako je celoj varoši poznato". Na kraju je u tome i uspeo i magistrat je zaista odbio Duki da prizna te troškove jer su se stariji senatori jasno sećali da je Duka obećao besplatnu hranu.

Onda je Jovan Muškatirović pronašao još jednu sumnjivu stavku u Dukinom računu. Ona je iznosila 27 forinti, a odnosila se „za košulje od serbskago platna". Tu stavku nije hteo da prihvati ,jerbo Gospoža jego Katarina napolu s gospožom Dukinicom prela i tkala jest", što će reći da je Ekatarina zajedno sa Dukinom ženom prela i tkala košulje koje su kasnije delile.

Interesantno je da Muškatirović nije priznao ni 100 forinti „troška ot veselja", a što se odnosi na troškove svadbe. Kako Muškatirović navodi, on (Muškatirović) snosio je sve troškove svadbe: „on vino crno i belo i rakiju šljivovicu, kuvare, muzikante, muntmel, puter, meso, divijač pokupovao, dakle govori da nije g. Duka o veselju jegovom ništa potrošio".

Na kraju, Muškatirović je u svim svojim zahtevima uspeo u potpunosti tako da je Duki presuđeno da Ekatarini isplati nasledstvo od ukupno 1400 forinti. Praktično, ovom parnicom Muškatirović je Duku skoro upropastio, a ovaj do kraja svoga života nije otplatio ovu sumu novca. Kada je umro 30. marta 1779. godine prodano je čak 109 jutara njegove zemlje (po ceni od 13 forinti). Nakon svega je na ruke Muškatirovića isplaćena tražena svota, a uz interes to je bilo 1580 forinti. Uz to išli su tu i sudski troškovi od 27 forinti.

19 Glasnik Istoriskog društva u Novom Sadu, sveska 30, Novi Sad 1937, str. 415.

20 lbid. 
Verovatno od ovoga novca kupiće Muškatirović tokom 1779. godine kuću u Curčijskoj ulici i to od trgovca Andrije Popovića. Cena kuće je bila 1200 forinti. Mnogo kasnije Muškatirović ce je prodati (kada bude selio u Peštu) za iznos od 1400 forinti.

\section{e) Boravak u Beču}

Tokom 1782. godine (25. jula) Muškatirović zastupa udovicu Isaka Isakovića, Nerandžu, pri otvaranju testamenta Tome Uskokovića koji je dugovao Nerandži 200 forinti. Testament niko nije osporavao, ali Muškatirović je tražio da se preostale Uskokovićeve stvari inventarišu.

Posebno je bitna parnica koje se Muškatirović prihvatio te iste godine (1782). Građanstvo Karlovaca bilo je nezadovoljno uređenjem takozvanih slobodnih militarskih komuniteta, ali i normom koja je važila još od 1753. godine. Kako se navodi: „Sad od početka 781. god. kako je G. major v. Esterraiher za oberinšpektora anštelovat i u Karlovce dišlocirat, to ot ono doba on po sistemu nemeckom i svojima projekti nas počeo novima teretima i službama pače običaja obremenjati". Pred kraj godine počelo je bivati neizdržljivo. Tada je izgrađivan put „s nasipom i kaldrmom ot Varadina do Zemuna". Upravo na njemu radilo je po 50 i više radnika, a da nisu bili plaćeni: „morali po 50 i više rabotnika badjava davati”.

Kada je stanje postalo neizdrživo građani Karlovaca izaberu između sebe šestoricu građana koje opunomoće da podnose tužbe i molbe. Muškatirović im je 10. novembra 1782. godine sastavio dopis kojim su se obratili pridvornom agentu u Beču, Karlu Bujanoviću. Tada je zatraženo da Karlovci postanu slobodan kraljevski grad, odnosno da se provincijalizuju. Taj posao sigurno nije bio lak budući da se od Bujanovića zatražilo da sve to drži u tajnosti pošto je postojala opasnost da molioci budu od strane vojnih vlasti proganjani. Uz molbu Bujanović je dobio potrebne dokumente i ponudu o otkupu regalia.

U odgovoru Bujanović se prihvata posla, ali traži još neke podatke. Uz sve to predlaže Karlovčanima da mu pošalju dva akova bermeta i akov auspruha kojima bi podmitio one od kojih možda zavisi uspeh ove molbe. Karlovčane ovi zahtevi nisu zbunili pa 5 . decembra 1782 . godine šalju tražena dokumenta i podatke. Za bermet kažu da će ga poslati prvom prilikom, a auspruh ne mogu jer se on u celom Sremu ne pravi, ${ }^{21}$ međutim mogu da pošalju staru šljivovicu. ${ }^{22} \mathrm{Uz}$ sve to pitaju grofa Balašu da li bi primio cmoga karlovačkog vina i šilera.

Nekako od ovoga momenta u sve se to uključuje i Muškatirović. Dana 25. septembra 1782. godine sudac Kašpar Hauk, senatori Marko Gojković, Jeremija Jovanović i Adam Koh ${ }^{23}$ daju Muškatiroviću i Buja-

$2 !$ Kako navode: ,illius nullusadhuc usus in toto Syrmio".

22 Navodi se: „antiquum Sylvorium”.

$23 \mathrm{Uz}$ njih i neki članovi komuniteta. Između ostalih Dimitrije Jovanović Sabov. 
noviću punomoć. Kako se navodi, sada njih dvojica treba da rade na elibertaciji Karlovaca ispod graničarske vlasti. Već 21 . oktobra 1723. godine pravi se između njih ugovor po kojem Muškatirović i Bujanović imaju pravo da u slučaju uspeha naplate nagradu od 80 dukata. Muškatirović odmah dobija 300 forinti da otputuje u Beč (ili Požun) i da počne sa radom.

Interesantno je navesti da je magistrat iskoristio priliku da 8. novembra 1783. godine Muškatirovića obaveže da u Beč povede i umno poremećenog senatora Maksima Vujića u zavod za lečenje umobolnih. Time se verovatno pokušalo smanjiti troškove Vujićevog oputovanja u Beč na najmanju moguću meru.

Sta je Muškatirović radio u Beču ostaje tajna, ali Karlovčani nisu bili zadovoljni njegovim ponašanjem. Prigovaraju mu da „istjazava”, a najveći problem je bio novac. Osim onih 300 forinti oni mu do 13. maja 1784. godine isplaćuju još 200 forinti. Ni to nije bilo dovoljno i Muškatirović im šalje račun (obligaciju) na još 100 forinti. To je izazvalo pravu uzbunu i nezadovoljni Karlovčani mu šalju pismo u kome kažu da je najnoviji račun (obligacija) „naše društvo uzbunila i na to dovela govoriti: Pomagaj ljudi, ovaj G.-din ili nas za budale sudi, ili nimalo vjerovati ne možet, i nikogda nesititi se ne mislit, no vse neprestano novaca ištet, a ne smatra što mi ljudi mršavi, a pače ješte u zamućenu i nimalo izbistrenu vodu trošak činiti nas pritežet, da uže sustali, i zato otrekli konačno ni krajcare pošilat. O čem nas nekoliko vam poznatih dovolno i mnogo truda upotrebili dokle jedva privolili ostali soglasiti, vam uže obještenih 100 f. za sad na ovu obligaciju i za posledni krat poslati, a više ni mislim ni možem ni smijem niže nadjejtesja".

$\mathrm{Na}$ kraju se ispostavilo da je celokupni trošak bio uzaludan jer je 29. januara 1785. godine njihov zahtev i konačno odbijen, a moliocima (komunitetu) je preporučeno da miruje.

Sve u svemu Muškatirović je mogao biti zadovoljan. Nije uspeo u parnici, ali je sa druge strane boravio duže vreme u Beču gde se upoznao sa Dositejem Obradovićem i Atanasijem Sekerešem. To će imati velikoga značaja za njegov kasniji književni rad.

I ovde treba pomenuti da je uspeo dopise očajnih Karlovčana da kasnije dobro upotrebi. U svojoj knjizi poslovica iskoristiće dve poslovice koje su mu Karlovčani u svojim pismima navodili. U jednom o pisama (od 11. decembra 1783) oni kažu: „Jerbo serbska poslovica pada nam do pameti: Prošloj kiši japunže ne treba". U drugom pismu (od 5. februara 1784) navode: „A sad posle boja kopiem u ternje”.

\section{f) Burne godine}

Sledeće dve godine će možda biti i najburnije u Muškatirovićevom životu. Neprilike u koje će naglo da uđe biće vezane uglavnom za advokaturu i način njenog vršenja. Najpre je Namesničko veće dana 14. aprila 
1784. godine izreklo Muškatiroviću preko Magistrata oštar ukor zbog nekih drskih izjava u pitanju Stefana Stojanovića, paroha na Čeneju. Ispad Muškatirovića je bio takve prirode da mu je priprećeno kaznom silentii.

Ni sama advokatura mu nije išla najbolje, pogotovo kada je reč o naplaćivanju usluga. Tokom oktobra (11) Muškatirović dobija od Namesničkog veća preko Magistrata odbijenicu njegove molbe da mu se za tri parnice koje je vodio u korist Narodnih fondova u Karlovcima, isplati kao nagrada 320 forinti. Kako se u odbijenici navodi, Muškatirović je parnice zaista vodio, ali ih je napustio pre nego što su završene. Kako Fondovi od njegovog rada nisu videli koristi, to su odbili da ga za dotadašnji rad plate. Tu se za Muškatirovića navodi: „in gremio Civitatis neoplantensis fixum domicilium".

Onda je došla možda i najteža parnica. Radilo se o raspravi imovine mitropolita Vikentija Jovanovića Vidaka. U sporazumu sa poveriocima Muškatirović je bio dodan kapetanu i auditoru Valkoni. Muškatirović je trebao biti konkurator imovinske mase iza pokojnog mitropolita. Uz sve to i on sam je imao potraživanja prema imovinskoj masi, zapravo, tražio je da naplati rad za fruškogorske manastire. U svojim potraživanjima uspeo je tek delimično. Kao fiškalu konzistorije priznato mu je 487 forinti, a kao fiškalu daljskog vlastelinstva (iz 1777. godine) svega 200 forinti.

Čini se da je Muškatirović bio u nekoj zavadi sa auditorom Valkonijem jer mu ovaj njegova (Muškatirovićeva) potraživanja ne stavlja u prvu klasu (koja se prva isplaćuju) ${ }^{24}$ već u četvrtu. Ta je klasa bila poslednja koja je dolazila na red za isplatu. Najčešće zbog nemanja dovoljno imovine nije ni isplaćivana ili bi bila isplaćivana u malom procentu ukupne sume.

Muškatirović se naljutio u tolikoj meri da se nije libio da optuži članove delegiranog Vojnog suda, a posebno auditora Valkonija, da su bili pristrasni, pa čak da je bilo i pronevera. Odmah je pokrenuta istraga u kojoj Muškatirovićeve optužbe nisu imale uspeha. Stoga je Namesničko veće naredilo Magistratu da protiv Muškatirovića pokrene parnicu zbog klevete. To je izvedeno veoma brzo i već 30 . septembra 1785 . godine svi spisi se šalju Namesničkom veću na odobrenje.

$\mathrm{Na}$ kraju je Muškatirović kažnjen sa kaznom silentii (nije mogao primati niti voditi parnice).

Upravo je ova afera mogla Muškatirovića stajati veoma skupo. Naime, u to vreme (1785. godine) Peštansko srpsko obštestvo traži od cara Josipa II da imenuje Muškatirovića za gradskog senatora. On je ispunjavao sve uslove za mesto senatora, ali zbog afere se sve odugovlačilo. Jedno vreme njegovo je imenovanje ostavljeno in suspenso.

Čini se da je u ovom otezanju oko Muškatirovićevog imenovanja imao umešane prste kapetan Valkoni. Kada je ovaj kapetan 1786. godine umro odjednom se pokazalo da Muškatirovićeve optužbe na račun Valkonija imaju u sebi dosta osnova. U svakom slučaju, ponovo se 4. septem-

$24 \mathrm{U}$ toj klasi bile su i plate posluge. 
bra 1786. godine caru Josifu II upućuje predlog da se Muškatirović imenuje za peštanskog senatora. Uslov je bio da najpre ispitom dokaže da ima znanja i sposobnosti koje se traže.

Nešto kasnije, 17. oktobra kasirana je parnica i presuda protiv Muškatirovića, zbog klevete na račun kapetana Valkonija.

Tokom rasprave ostavine pronađena su dva pisma kod mitropolita Vikentija Popovića. U jednom (iz 1785. godine) Muškatirović moli mitropolita da mu pošalje 1000 forinti, dok se u drugom (kasnijem) zahvaljuje na novcu koji je primio. Komesar Baho je tada zatražio da Magistrat od Muškatirovića zatraži objašnjenje o kakvom se to novcu radi. No, Magistrat (30. oktobar 1786) se izvinjava da to nije u stanju uciniti jer nije u stanju doći do Muškatirovića koji je stalno na putu, te se uglavnom nalazi u Pešti ili Beču.

Konačno 6. marta 1787. godine Baho uspeva da ispita Muškatirovića. Njegovi odgovori su bili pravi advokatski. Naime, Muškatirović navodi da onaj koji je u stanju tendenciozno da reprodukuje dva nejasna pisma, sigurno je u stanju da reprodukuje i druga pisma koja bi ove nejasnoće otklonila. Nadalje, odbija da bilo šta detaljnije obrazloži jer po zakonu i nije obavezan reći da li je novac od pokojnika, koliko je i pod kojim uslovima od njega primao novac. Onda je direktno napao i predložio da ako kurator mase ima osnove, neka ne čeka, već neka pokrene parni$\mathrm{cu}$, a Magistrat zna da to samo prouzrokuje troškove. Nakon ovoga podsetio je da je slično prošla i parnica protiv njega koja je kasirana. Na kraju treba napomenuti da se na ovome zapisniku Muškatirović potpisao samo kao advokat.

I konačno, 29. jula 1788. završena je i ostavinska rasprava iza mitropolita Vidaka. Na kraju je Muškatirović (kao konkurator) naplatio svoje usluge (u vremenu od decembra 1781. godine do 27 . avgusta 1787. godine) u iznosu od preko 800 forinti.

Snalažljivi Muškatirović je i kod rasprave ove ostavine (mitropolita Vidaka) uspeo da radi kao advokat. Tomi Bariću iz Osijeka je izradio da iz ostavine ovaj naplati 8000 forinti svoga potraživanja. Obećana nagrada je bila 200 dukata, ali je Barić odbio da to isplati. Na kraju je Muškatirović vodio parnicu radi naplate ovog potraživanja protiv Barićeve udovice.

\section{g) U Pešti}

Pre odlaska iz Novog Sada, Muškatirović je prodao svoju kuću (18. avgust 1787). Kupac ove kuće bio je Dimitrije Gadeša. Cena je bila 1400 forinti. Gadeša je isplatio 400 forinti, dok je za ostatak od 1000 forinti izdao priznanicu (obligaciju). Na kraju, Muškatirović nije mogao ni ovo naplatiti. Dug se vukao jedno vreme, a Muškatirović se uspeo naplatiti tek kada je Gadeša umro i to iz njegove ostavine. To je bilo tek 1795. godine. Tom prilikom je siročadski otac strahovito izgrdio Muškatirovića i okarakterisao ga kao „dosadna kverulanta”. 
Od 1787. godine bio je senator opštine u Pešti: „Prvi Srbin koji je bio izabran (1787. g.) za peštanskog gradskog senatora bio je advokat i pisac Jovan Muškatirović, u to vreme prvi Srbin sa advokatskom diplomom". 25

Taj će položaj zadržati duže vreme, a u svojoj autobiografiji Sava Tekelija se hvali kako je on bio taj koji je Muškatiroviću pomogao da bude ponovo izabran za senatora: „To isto sam radio i za Peštu gdi Muškatirovič racherom nanovo posta. I tako se uvede da sad ot naši u te dve varoši rachera imade, što pre nigda bilo nije". ${ }^{26}$

Kako je bio jedno duže vreme jedini srpski advokat u Ugarskoj, to je Muškatirović među tamošnjim Srbima uživao veliki ugled. Kao senator bio je predstavnik mnogobrojnog i veoma imućnog srpskog elementa u Pešti, a osim toga održavao je veoma česte i tesne veze sa Srbima u tzv. „donjim krajevima”, odnosno u južnoj Ugarskoj.

Upravo će 1790. godine Muškatirović na Temišvarskom saboru da odigra značajnu ulogu. Ovaj sabor igra uz Majsku skupštinu (1848) i Blagoveštenski sabor (1861) najznačajniju ulogu od svih političkih sabora koje su Srbi držali u Ugarskoj. Njegov raspravni deo je trajao od 26. avgusta do 4. novembra. Održano je 24 sednice, a tu ce biti za novoga arhiepiskopa izabran Stefan Stratimirović.

Muškatirović je od samoga početka bio umešan u pripreme za ovaj sabor. Ostalo je sačuvano dosta njegovih pisama koja su vezana za pripremu i njegovo održavanje.

Tako se zna za njegovo pismo mitropolitu Mojsiju Putniku (poslano iz Pešte 2. februara 1790) gde on obaveštava mitropolita o antijozefinskom raspoloženju u Ugarskoj i o otporu županije prema dvoru. Zato predlaže da Putnik, na čelu delegacije, pođe u Beč radi rešavanja narodnih poslova. ${ }^{27}$ Kako je mitropolit oklevao Muškatirović ga 25. marta/14. februara podstiče na put u Beč i na sastavljanje narodnih "gravamina i postulata", smatrajući da je povoljno vreme za intarkulaciju srpskih privilegija. ${ }^{28}$ Muškatirović ponovo iz Pešte (pismo od 5. marta/24. februara 1790) predlaže mitropolitu kako da se prikupe argumenti o srpskim privilegijama i savetuje da se u Pešti formira deputacija koja bi uz saradnju istoričara Jovana Rajića trebalo da pripremi narodne zahteve. ${ }^{29}$

No, za Muškatirovića nije teklo sve tako lako. Imao je on svojih protivnika koji iz Budima pismom od 3. juna/23. maja 1790. godine odbacuju njegov plan o učešću Srba na Ugarskom saboru i izjašnjavaju se za sopstveni Narodni sabor za koji mitropolit treba da izdejstvuje dozvolu od cara. Kako se navodi: „Čto Djelo i Plan gospodina Muškatiroviča, dje-

25 Ż. Milisavac, Istorija Marice srpske, I deo, Novi Sad 1986, str. 109.

26 Sava Tekelija, Opisanije života moga, Beograd 1989, str. 26.

27 Arhiv Srpske akademije nauke i umetnostiu Sremskim Karlovcima, Patrijarsijsko-mitropolijski arhiv "A", 53/1790.

28 lbid.

29 lbid. 
lo je jedinago privatnago čelovjeka i više v sebje ne soderžajet razvje jedini votum aki jedinago deputaciji sosjedatelja, sljedovatelno takovij torŽestvenija deputaciji predmjet biti ne možet...".30

Muškatirović nije bio usijana glava niti revolucionarno raspoložen tako da iz Pešte 5. juna/25. maja 1790. godine u pismu mitropolitu Putniku optužuje svoje protivnike i izjašnjava se protiv održavanja Srpskog narodnog sabora u želji da Srbi ne pogoršaju svoje odnose sa Ugarskim saborom, jer treba računati da će Dvor ipak pre zadovoljiti Mađare nego Srbe. ${ }^{31}$

Mitropolit Putnik u svome pismu iz Beča od 9. juna/29. maja 1790. godine obraća se Muškatiroviću i izražava žaljenje zbog nesloge izmedu njega (Muškatirovića) i drugih viđenijih Srba, koji su izgubili veru u Mađare. Najavljuje razgovor s njim nakon dolaska iz Beča u Peštu: „Tamo $\mathrm{k}$ Vami priti i potom obširno o djelje našem $v$ licje razgovoritsja budem". ${ }^{32}$

U pismu iz Pešte od 24/13. juna 1790. godine Muškatirović obaveštava mitropolita o radu Ugarskog sabora i predlaže da Srbi u svoje zahteve unesu i predlog o prevođenju oficira plemića u plemstvo, te da se plemstvo dodeli i nekim spahijama pravoslavne vere. ${ }^{33}$

Za Ugarski sabor izradio je Muškatirović tokom jula 1790. tzv. „Punkta" u kojima govori o veri i sveštenstvu, srpskom i rumunskom narodu i njihovim zaslugama za Ugarsku. Stoga predlaže da se ozakone srpske privilegije, pravo učešća na Saboru, pravo na upravnu službu i druge povlastice, a sve kako bi se pravoslavni izjednačili sa drugim narodima u Ugarskoj. ${ }^{34}$

Na kraju je Muškatirović u Sremskim Karlovcima 29/18. jula 1790. godine izradio tzv. „Nacrt srpskog memoranduma vrhovnoj vlasti” u našoj istoriografiji nazvan sa „Elaborat". ${ }^{35}$ Upravo će ovaj memorandum da bude pročitan na saboru, a pisac anonimnog dnevnika o radu sabora navodi: „Pročten bist plan G. Joana Muškatirovića, peštanskija kr. varoši se-

30 Pismo objavio D. Ruvarac u Glasniku Istoriskog drušrva u Novom Sadu, knjiga II, 1929, str. 224/225. Danas je ovo pismo u Arhivu Srpske akademije nauka i umetnosti u Sremskim Karlovcima, Patrijaršijsko-mitropolijski arhiv „A”, 117/1790.

31 Pismo objavio D. Ruvarac u Glasniku Istoriskog društva u Novom Sadu, knjiga II, 1929, str. 222/223. Danas je ovo pismo u Arhivu Srpske akademije nauke i umetnosti u Sremskim Karlovcima, Patrijarsijsko-mitropolijski arhiv „A”, 118/1790.

32 Danas je ovo pismo u Arhivu akademije nauke $\mathrm{i}$ umetnosti u Sremskim Karlovcima, Patrijař̌ijsko-mitropolijski arhiv „A", ad 118/1790, koncept.

33 Arhiv Srpske akademije nauke i umetnosti u Sremskim Karlovcima, Patrijaršijsko-mitropolijski arhiv ,A", 122/1790.

34 Tekst je objavljen u Srpskom Sionu za 1904. godinu, str. 583-586.

35 O ovome tekstu biće više reči u onom delu gde se budu obrađivali Muškatirovićevi književni radovi. Ovde reći da je celokupni tekst memoranduma objavljen u Srpskom Sionu za 1905. godinu na str. $421-425,453-460,517-521,569-571,583-586$. No, ovde i napomena. U Srpskom Sionu objavljena je nešto skraćenija verzija dok se proširena nalazi u Rukopisnom odeljenju Matice srpske, M. 11556. Treba napomenuti i da je verzija iz Srpskog Siona objavljena u knjizi Temišvarski sabor 1790. Novi Sad-Sremski Karlovci 1972. str. 155-181. 
natora, sostavlen i o blagostojanii klera i Naroda našego da urazumjejut kako i ot koih vremen Narod naš s kraljami ungarskimi sprjaženia imjeet i kudu rasprostranjalsja i oderžanie svoe imjel..."36

Nakon održanog Sabora u Temišvaru, život je išao dalje. Od 1794. godine Muškatirović je i "mesni nadziratel” srpske škole u Pešti.

\section{h) Muškatirovićev književni rad}

U Narodnoj enciklopediji pod odrednicom Jovan Muškatirović je našao svoje mesto skoro isključivo kao pisac, odnosno prvi skupljač narodnih poslovica. Da je advokat, tek se uzgredno navodi. O njemu kao piscu se kaže: „M. zauzima vidno mesto u istoriji srpske prosvećenosti uglavnom zbog toga što je bio prvi Dositejev sledbenik, koji je njegove ideje dosledno, pametno i višestrano provodio i što je prvi počeo skupljati i objavljivati narodne izreke i poslovice". ${ }^{37}$ Osim toga on je jedan od prvih koji je svoje knjige pisao narodnim jezikom, prvi značajniji srpski književnik koji je to činio bio je Dositej Obradović. ${ }^{38}$

\section{1) Kratko razmišljanje o praznicima}

U nekom od svojih advokatskih poslova Muškatirović je 1786. godine otputovao u Beč. Ne zna se šta je bio konkretan posao, a on sam navodi „radi djela moji pri Pridvornih dogodivšihsja”. Izgleda da je tu stupio u vezu sa Dositejem Obradovićem i Atanasijem Sekerešem. Dositej je dovoljno poznata ličnost tako da o njemu nije potrebno bilo šta detaljnije govoriti. Atanasije Sekereš, učeni srpski sveštenik, u vreme kada je Muškatirović dolazio u Beč bio je srpski paroh u austrijskoj prestonici. Umreće 1800. godine, a o njemu se Dositej izražavao veoma pohvalno smatrajući ga boljim i učenijim od sebe. Postoje izvesne indicije da se Sekereš pred kraj života pounijatio. ${ }^{39}$

U vreme kada je Muškatirović dolazio u Beč, Sekereš je bio cenzor srpskih knjiga. Muškatirović se tada nije bavio samo svojim advokatskim poslovima već je sa Sekerešem kontaktirao i oko izdavanja svoje prve knjige. Sekereš ga je primio veoma ljubazno i imao dobro mišljenje o Muškatirovićevom književnom prvencu, a čini se da ga je i sam Dositej ohrabrivao da izda knjigu. To im Muškatirović nije zaboravio, tako da ih u predgovoru svoje knjige pominje kao „ljubeznike”.

36 Temišvarski srpski narodni sabor 1790. godine, Arhiv za istoriju Srpske pravoslavne karlovačke mitropolije IV, 1914, 6-50.

37 S. Stanojević, Narodna enciklopedija, srpsko-hrvatsko-slovenacka, knjiga Il, Zagreb 1929, str. 928/9.

$38 \mathrm{O}$ jeziku kojim je Muškatirović pisao svoje knjige pogledati kod A. Albin, $O$ narodnom jeziku Jovana Muškatirovića, Zbornik MSFL XII (1969), str. 53-72. 167. i dalje. 
I baš te godine (1786) izlazi prva Muškatirovićeva knjiga pod nazivom Kratko razmišljanje o praznicima. Knjiga je, dakle, izašla 1786. godine u Beču, pisana je građanskom azbukom i kako J. Skerlić navodi „na relativnom dobrom narodnom jeziku". ${ }^{40}$

$\mathrm{Na}$ Dositeja je ova knjiga ostavila dovoljno dobar utisak da o njoj navede: „Mala, no prepolezna o praznikah knjižica gospodinom Joanom Muškatirovičem. peštanskim senatorom, sostavljena i izdata, dostojna je vseopšteg čtenija. Ovi učeni i za svoje userdnjejše otečestvu i svoj naciji dobroželanije dostohvalni muž premudro u rečenoj knjižici dokazuje: šta su praznici, kako su postali, kako valja da se razumno praznuju, i kakova šteta od njih proishodi kad se nerazumno u lenosti provode i zloupotrebljavaju".

Treba reći da ovo nije bila Dositejeva tek kurtoazna pohvala. On će se tih dana u Beču, kada je dosta vremena provodio sa Sekerešem i Muškatirovićem, kasnije prisetiti u svojoj knjizi Etika koja je izašla u Veneciji 1803. godine. 41

Čini se da je Muškatirović knjizi Kratko razmišljanje o praznicima zamislio jedino praktičan značaj. Tu nekih literarnih ambicija zaista nema. U to vreme državna vlast je pokušavala da kod pravoslavnih Srba smanji izrazito veliki broj verskih praznika. Jedno vreme postojalo je 170 dana praznika (zajedno sa nedeljama). Samo u mesecu julu (sem nedelja) bilo je 15 praznika, a u maju (bez nedelja) 13 prazničnih dana. Još 1769. je ukinuto 69 praznika (odnosno - ostalo 52 nedelje i 68 praznika), a onda je 1774. godine izbrisano još 27 praznika.

Nije to bilo lako uraditi i Sinod je tek pod pritiskom državnih vlasti bio prinuđen da ovako drastično smanji broj verskih praznika. Na kraju se pokazalo da je i to bilo nedovoljno jer je car Josif II tokom 1784. godine naredio Sinodu da se opet i taj smanjeni broj praznika još proredi. Tako je i bilo. Siod je, opet preko volje, tokom 1786. godine revidirao broj verskih pravoslavnih praznika (ukinuto 15 praznika, odnosno, ostalo 25 sem nedelja).

No, sve to nije išlo tako lako, pa je bilo i prisile. Navodi se da su bili određeni posebni oficiri koji su išli od crkve do crkve i pratili da li se naredbe Sinoda izvršavaju. Prost narod se bunio. ${ }^{42}$ Koliko je to uzelo maha vidi se iz toga što je 26. oktobra 1777. godine u Vršcu vladika Vikentije Popović umalo poginuo od razbesnele rulje. Izvukao se tek onda kada je obećao da se praznici i dalje mogu slaviti po starome. ${ }^{43}$

40 J. Skerlić, Srpska književnost u XVIII veku, Beograd 1966, str. 376.

41 Izašla u Veneciji 1803. godine. Zapravo, Dositej se više obraća Sekerešu, a Muškatirović se tek spominje. „O. Sekerešu! Ti ljubezna dušo! Tebe sam dužan ovde spomenuti. Kad bi god otpuštao g. Muškatirovix̌a i mene od sebe, rekao bi nam: 'Dolazite mi! Dolazite mi često, ne bojte se da ćemo se napreljubiti. Život je kratak"”, str. 124.

42 Ostalo je zapisano da su Srbi iz Budima pisali: „Nami naši svetci nesut za kasiranje ni za otmet, zašto mi ot njih ne nahodimo nikakve štete ni ubitka najmanjega u svoj našoj radnji, nego jošte, Boga črez njih slavešte, osećamo blagoslovenije i veliku milost Božiju u svačemu na nama".

430 tome pisao D. Ruvarac, Pravila za kaludere $i$ sveštenike $i$ reglament od 2 . januara 1777. Književno istorička crta iz prošloga veka. „Javor", 1887. str. 281. 
Kako se car Josif II smatrao prosvećenim vladarem to je srpska inteligencija skoro listom bila pristalica njegovih reformi. To se odnosi i na Muškatirovića koji je svojom knjigom pokušao da objasni dobru nameru vlasti, ali i veliku korist koja se dobija takvim reformama. Sam Muškatirović nije bio prvi koji je govorio o prevelikom broju verskih praznika. Prije njega je to učinio Dositej Obradović, ali tek uzgred. Mi danas znamo da je upravo pod njegovim (Dositejevim) uticajem Muškatirović se usudio da piše svoju knjigu.

Sama knjiga je bila veoma hrabra za to vreme tako da ju je i Safarik nazvao pomalo i pogrešno „slobodoumnom protiv praznika”. Knjiga nije bila slobodoumna u onom teoretskom smislu i Muškatirović u njoj nije izlagao nikakve "slobodoumne” ideje. On je jednostavno pokušavao da opravda državne mere protiv velikog broja praznika u Srpskoj pravoslavnoj crkvi. Kao svoju nameru on navodi da je ,hteo da se pravoe svojstvo praznikov pozna. I onako kako hristijanom trebuje s molepstvijem i upražnenijem u nauki Božiej, ono vreme provodi se". Zatim „da se sujevjerije opovergne", kao i da se ukinu praznici paganskog ili muslimanskog porekla, te da Srbi „bez roptanija povinujetsja” svim "nareždenijam cesaro-kraljevskim i sinodalnim".

Kroz knjigu Muškatirović daje istoriju verskih praznika. Navodi da nema pouzdanih dokaza da je Hristos naložio praznike, odnosno da su ustanovljeni Svetim pismom. Isto tako iz dela i poslanica apostola i crkvenih otaca vidi se da nije bilo tačno određenih dana koji su utvrđeni za molitve i crkvenih zabrana da se ne radi u određene dane. Tek kasnije počinju se gomilati praznici od kojih je ,bolšaja čast plod nevježestva i sujeverija”. U najčistija vremena hrišćanstva „egda sujevjerije nije obladalo bilo, glavnoe praznovanije hristijanov, ne u neradjeniju iliti inima kakovima nepristojnima upraždenijama sostavljalo se, kako sada po bolšoj časti što biva; no i molitvi i blagogovni upražnenija a posle ovih, najpače zemlodelci radili su".

Nadalje, Muškatirović navodi da praznovanje nije sastavni deo hrišćanske vere, no je „vesma škodliv i ubitočen” običaj koji treba suzbijati. Kako praznoverice zahvataju hrišćanski svet, to je potrebno da „carevi zemleni i načalnici o semu promotre, i ovo zlo novi zakoni i ustavi opovergnu". Nadalje navodi kako su već Rusi smanjili broj praznika, a to je učinila i katolička crkva.

Kao primer Muškatirović navodi jednu rečenicu koja je danas isto tako aktuelna. On kaže da Srbi nikako ne treba da zaboravljaju onu svoju poslovicu koja za crkvene knjige kaže da su ih „Grci napisali, Moskovi naštampali, a Serbli se derže”. Kod Srba u tadašnje vreme „egda mati nevježestvo i kći sujeverije preobladale su”, namnožili su se oni praznici kojih ne bi smelo da bude i koji nemaju nikakve veze sa hrišćanskom verom. Srbi daju osobine svetom Iliji koje ima i rimski Jupiter, a sveti Nikola se slavi kao paganski Neptun. Kao primer Muškatirović navodi da se od Uskrsa do Spasovdana praznuje svaki četvrtak, a to je praznovanje Jupiterovog dana. 
Uz sve to i žene slave svoj praznik, i to turski. Naime, žene slave svaki petak: „U svakom narodu, žene, po nemošnoj naravi njiovoj, uvek se u svačemu dadu prevertiti, neželi muškoga pola ljudi". Ovo je bilo zaista tačno jer se i u Srbiji tokom XVIII veka slavio petak u tolikoj meri da je srpski sabor od 1730. godine u Beogradu rešio da se najstrožije kazne svi oni koji slave petak.

I kao poslednji razlog zbog čega treba manje praznika, odnosno neradnih dana, Muškatirović navodi da je danas čovek ,dužan s radom svojim zaslužiti, i u carsku kasu, za soderžanije voinstva, i mirni život svoj platiti”. Osim toga treba raditi i da se preživi, da čovek nabavi „prepitanije i odjejanije kako samago sebe, tako i domašnjih svojih".

Sa ovom knjigom Muškatirović je imao sve same neprilike jer ga je na kraju karlovački mitropolit tužio (zapravo, tužio je stampara Kurcbeka) zbog štampanja te „Bogohulitelne knjige”.

\section{2) Rasuždenie o postahi vostočnii cerkve}

Plašeći se da opet ne bude neprilika sa Srpskom pravoslavnom crkvom Muškatirović sledeću knjigu ne potpisuje i ona izlazi pod drugim imenom (Samuel Klajn). Nova knjiga je izašla pod naslovom Rasuždenie o postahi vostočnii cerkve. Knjiga je rađena crkvenom azbukom i na slavjano-serbskom jeziku sa velikim mešavinama narodnoga jezika. Stampana je u Beču 1794. godine. U njoj se Muškatirović pozabavio onim postovima koji su tada bili prisutni u Srpskoj pravoslavnoj crkvi.

I ova je knjiga rađena pod uticajem Dositeja Obradovića koji u Životu $i$ priključenijima dosta oštro nastupa protiv onih koji se zalažu za strogo držanje postova; „Neću da si kao oni koji hue s anatemama na sve one što u sredu i u petak zejtin i ribu jedu... sav svet da ti reče da će Bog u vječnu muku i u vražje ruke predati one koji jedu u sredu i u petak ribu i meso, nemoj mu verovati; to nije moguće, to ni turski car ne bi učinio. To je bezumije i huljenije reći da pravedni Bog može takovu užasnu i nečuvenu nepravdu učiniti. Ali su sveti oci anatemi i vječnoj muci predali one koji u poste ribu i meso jedu".

Ova Muškatirovićeva knjiga je pisana u obliku pisma nekom svom „ljubeznom drugu”. Tako i počinje: „Hoštu ti ono napisati čto obretoh kod preždnih pisatelej čto blagogovjenstva pravi razum i polza ste matere cerkve s soboju nosit". On navodi kako je u prvo vreme hrišćanstva post bio jedino sredom i petkom kao i za vreme "Cetrdesetnice”. Strog i dugi post jedino se držao u manastirima. Vremenom, kako su monasi dobijali sve veći značaj i vlast u hrišćanskoj crkvi (episkopi se biraju isključivo iz reda monaha), to su monasi svoje manastirske tipike (pravila) pokušali da nametnu svima. Na neki način terali su ceo svet da prihvati njihov način posta pa su svi morali „post po monašeskomu uvetu hraniti”. U vreme kada je Muškatirović objavio svoju knjigu od 365 dana u godini bilo je 200 dana posta (danas je veoma slično). 
Muškatirović navodi da je ovako strog post prisutan jedino na neobrazovanom Balkanu, dok kod ostalih država to nije tako: „Bojari, velika gospoda i mnogi znameniti ljudi v Rosiji, Valahiji, Moldaviji i v Hungariji, naipačeže činovnici putešestvujušti i po vsjudu živušti tergovci vostočnago ispovedanija zakona, ili malo, ili nimalo post nehranjat, i zato ni u cerkve prokleti, niže osobitoj kazni podverženi bivajut". Postiti je dobro, ali uvek umereno i iskreno, jer se onda ne škodi zdravlju. Ne treba postiti kao „naši prosti ljudi” koji bi prije umrli negoli u vreme posta pojeli jaje ili popili mleko. Smatralo se da je manji greh nekoga ubiti negoli pojesti u postu zalogaj mesa. Nesreća je srpskog naroda i pravoslavlja što neuki i sebični monasi držeći se „kore, a ne jezgra zakona i vere” vode narod „bolšej gluposti, nevoli, smetnji i prokletinji”.

Onda dodaje, da je post izmišljen tamo gde je u izobilju maslina, voća i ribe, a ne u Srbiji gde je posna hrana skupa ili se dobija trula i škodljiva za zdravlje: „Pravila domostrojitelstva i naravna mudrost uče nas da s sokrušenim sercem, veseloju voleju, a ne silom" držimo one postove koji su ustanovljeni izričitim crkvenim zakonima. Ostale postove koje su izmislili „drevni monasi” neka oni sami i drže, a ne da ih nameću drugima. Konačno, čovek se ne ceni po postovima već po svojim dobrim delima.

Na kraju svoje knjige Muškatirović kaže: „Č sam ovde pisao, dobrim primi serdcem, i veruj mi da sam i ja sve dobrim namjerenijem, a iz ljubavi k svjatoj materi našej vostočnoj cerkvi napisao; ako polzu kakovu vosprimeš, to mne budet vozmozdedije i radost, koi sam obikao vse na polzu drugih obraštati”.

Obe Muškatirovićeve knjige su čisto praktične i kao takve nemaju neke književne vrednosti. Ni on sam nije hteo da stvara književno delo tako da navodi mnoštvo praktičnih razloga koji brane njegova razmišljanja. Upravo su ti delovi najvredniji jer su u njima zapažanja o tadašnjem životu i običajima koje ima srpski narod. Iako obe knjige zalaze u teološka pitanja, Muškatirović ne pada u klopku i upušta se u raspravu o njima. Kao advokat, uz to ne baš crkven čovek, on i nije bio upućen u dogmatiku srpske pravoslavne crkve, i - toga je svestan. Međutim, u tim delovima on se poziva na neke druge pisce, a to i ne krije i u knjizi o postovima on to i najavljuje: „Hoštu ti ono napisati čto obretoh kod preždenih pisatelej".

U knjizi o praznicima on se poziva na Rudolfa Hospiniana (protestantski teolog iz XVII veka). Zapravo, Muškatirović je pod velikim uticajem protestanata i svi oni razlozi koje on navodi protiv crkvenih praznika i postova jesu razlozi koje su navodili protestantski pisci. No, to mu ne treba smatrati nekim velikim grehom budući da su mnogi srpski pisci iz XVIII veka pali pod taj isti uticaj (Zaharija Orfelin, Jovan Rajić, Dositej Obradović, Stefan Novaković, itd.). 


\section{3) Pričte ili po prostomu poslovice}

Ako je u ove svoje dve knjige Muškatirović na liniji slobodne i racionalističke misli Dositeja Obradovića, dakle, bez sopstvene originalnosti, onda je na jednom drugom polju on mnogo značajniji i nadasve originalan. Muškatirović je prvi pravoslavni Srbin koji je stao pribirati narodne umotvorine. Upravo stoga Matica srpska je 1866. godine slavila stogodišnjicu kako je izašla Muškatirovićeva zbirka poslovica. Tada je prvi put kod nas u jednoj štampanoj knjizi zabeležena narodna umotvorina. ${ }^{\text {t4 }}$

Tokom 1867. godine u Beču izlazi Muškatirovićeva zbirka poslovica pod nazivom Prictete. Ova je knjiga posvećena njegovom sinu Petru: „Joan Muškatirovič dražejšemu pervencu svome Petru Muškatirovič zdravstvovati želi". Posveta je ispisana 16. juna 1786. godine. Nadalje on sinu Petru govori: „Mnoga preizredna pravila iskustvom potverždena za život naučićeš: pri tom mnoga svojstva, sile i krasnorječija našego serbskago jezika dobićeš".

Muškatirović je smatrao da je vrednost poslovica (Pričta) velika, a njima su se služili svi veliki ljudi na svetu pa nabraja cara Solomona, Hrista, itd.: „Sto god je velikih ljudi na svetu bilo, sve su poslovice i rečenija u počitaniju i u upotrebleniju imali".

Kako je bio svestan velike vrednosti poslovica i izreka to ih je $\mathrm{Mu}$ škatirović odlučio sakupiti, tim više što ih ,na našem serbskem jeziku ešte niko nije sovokupio, a ešte manje nih na štampu izdao". Upravo stoga je on (Muškatirović) sašio naročitu svesku i iz dana u dan kako ih je čuo beležio sa namerom da ih izda „za polzu jedino - jezičnikov" svojih. Kada je sakupio odreden broj poslovica pokazao ih je svojim „ljubeznicima", a posebno navodi Atanasija Sekereša i Dositeja Obradovića, koji su ga ,jedinodušno sovjetovali i nastojali što bi sobranije ovo na štampu izdao, i ot ove strane rodu našemu k prosvešteniju služio". Upravo stoga Muškatirović štampa ovu knjigu „s userdjejšim i tepljejšim želanijem; čto bi onaj, koji vo tvoreniju služe tvorili; onaj pak koji zapreštajutsja izbegnuli; onaj na posledok, koji vo uveseliniju služe $s$ nima dolgoletno uveseljavali se".

Knjiga je imala velikog uspeha tako da je 1807. godine štampano u Beču i drugo izdanje. U tom drugom izdanju dodane su i neke nove poslovice i izreke. Oba izdanja su štampana crkvenim slovima. Inače, u drugom izdanju Muškatirović proširuje posvetu tako da osim najstarijem sinu Petru knjigu posvećuje i svom drugom sinu Simeonu: „Joan Muškatirovič dražajšim svojim sinovim Aleksandru i Simeonu, blagoslov Božji, i pokraj njega, svako dobro, i zdravlje želi". Posveta je pisana u Pešti 2. maja 1807. godine.

44 Ova knjiga je izazvala i izaziva i dalje veliku pažnju. O njoj su pisali A. Saulić, Jovan Muškatirović, prvi sakupljač srpskih narodnih poslovica, Južnoslovenski filolog, XXI (1955-1956), str. 237-255; M. S. Lalević, Muškatirovićeve „Pričte” kao elnografski materijal, Glasnik Etnografskog instituta SAN, II-III (1953-1954), str. 845-849.

45 Naziv je mnogo duži, ali za potrebe ovoga rada upotrebljen je ovaj kraći. 
O toj knjizi će Josif Dobrovski u Slovanki iz 1814. godine da napiše nekoliko primedbi. Govoreći o novim srpskim knjigama on spominje Muškatirovićevu knjigu Pričta i zamera mu što poslovice nisu bolje sakupljane, ali ističe njihovu veliku vrednost za leksikologe. S druge strane i Kopitar je znao za ovu knjigu, ali on o njoj već nije dobro mislio. Stoga je savetovao Vuka Karadžića da sakuplja poslovice na drugačiji način od Muškatirovića, tražio je od njega (Vuka), ,jednu čisto srpsku zbirku narodnih poslovica, ali ne kao Muškatirović izmešanu s prevodima nemačkih, latinskih, madžarskih, itd., već samo takvih koje se u srpskom narodu čuju".

No, Vuk Karadžić je ipak koristio Muškatirovićevu zbirku, a to izričito i spominje u predgovoru svoje knjige Narodne poslovice $i$ druge različne kao one u običaj uzete riječi. ${ }^{46}$ Tako Vuk navodi: „Iz poslovica koje je pokojni Jovan Muškatirović skupio i izdao (prvi put u Beču 1787, a po drugi put u Budimu 1807. godine) uzeo sam one za koje sam slušao da se po narodu govore, i za koje niko ne može reći da su sramotne".

Knjigu poslovica i izreka Muškatirović je napisao dobrim narodnim jezikom, a to je u to vreme bila velika retkost. U knjizi ima mnoštvo izreka i poslovica sakupljenih sa strane (nemačkih, mađarskih, latinskih, itd.), ali ima i srpskih narodnih poslovica. Tako ih Muškatirović i obeležava (,bačka”, „servijanska”, „ličanska”, „potiska”, „dalmatinska”). Za neke navodi kojem staležu pripadaju (,prostačka”, ",hersuzka”, ,pustaijska", „zemljodelcev poslovica”). Interesantno je da na nekim mestima navodi i od koga ih je čuo (tako kaže za dve da je čuo od nekog "Sime odžačara”). Između ostalih tu su poslovice „Baš mu pala sekira u med”, „Besposlen pop jariće krsti”, „Bez starca nema udarca”, „Boji ga se kao vrana skeledžije”, "Vrana vrani oči ne vadi”, "Gori mu glava ko futoškom knezu”, „Dalje se pruža od gubera”, „Zec u šumi, a on ražanj pravi", „Kad se mator panj upali, vesma gori", „Na psu rana na psu zarasla", itd.

Ova knjiga nije strogo zbirka poslovica, u njoj ima i nekoliko narodnih priča, anegdota, pomena o narodnim tradicijama, a ima i stihova iz narodnih pesama. Ono što je posebno ubolo oči tadašnjim čitaocima jeste veliki broj pornografskih izreka i reči. Sve je to bilo u skladu sa Muškatirovićevim stavom da se ,pero i papir ne stide”. O tim pornografskim poslovicama posebno je pisao Tihomir Đorđević u knjizi koja je izašla u Lajpcigu 1908. godine.

\section{4) Projectum pro graviminibus et postulatis Rascinae anno $1790 .$. elaboratum}

Pričte su značajne i zbog toga što je u njima Muškatirović pokazao i zainteresovanost za srpsku istoriju. I inače u to vreme svi obrazovani Srbi

46 Knjiga izašla na Cetinju 1836. godine. 
su se veoma interesovali za srpsku istoriju. Negde nakon 1790. godine, posle istorije koju je izdao Pavle Đulinac, ali prije Cuvene Istorije Jovana Rajića, i Muškatirović je napisao jednu istoriju srpskog naroda u Ugarskoj.

Ne zna se mnogo o tome rukopisu jer je sačuvan samo jedan odlomak objavljen u Srbskom letopisu za 1844. godinu. U knjizi 65, na stranama 68-82. pod naslovom Certe serbskoga života u Ungariji. ${ }^{47} \mathrm{Da}$ se radi o delu mnogo šireg rukopisa vidi se iz primedbe uredništva koje je zabeležilo na rukopisu: „Ovo je odlomak iz većeg dela, koje je Jovan Muškatirović, senator peštanski, 1790. napisao. Iz ovog se već vidi kako se ovaj rodoljubac o stvarma našega naroda bavio, i kako mu je narodna povesnica na srdcu ležala. Laka mu zemljica, blažena mu pamet".

Neki danas misle da je odlomak koji je objavljen u Srbskom letopisu zapravo tek istorijski uvod u neku od advokatskih odbrana srpskih privilegija kod vlasti u Beču. ${ }^{48}$ To je upravo onaj tekst koji je citan na Srpskom narodnom i crkvenom saboru u Temišvaru 1790. godine: „Na sednici od 19. avgusta pročitao je Stefan Monasterlija elaborat senatora peštanske varoši Jovana Muškatirovića o stanju našeg sveštenstva i naroda". 49

Izveštaj je uglavnom dobro prihvaćen, ali ipak bilo je i onih koji su bili veoma nezadovoljni tako da je došlo skoro do incidenta: „Sa izveštajem su bili svi zadovoljni sem Marka Serviskog. To je mnoge nerviralo, a naročito vršačkog episkopa Josifa Sakabentu koji mu je dobacio: 'Što vičeš toliko. Ako nećeš da slušaš, a ti idi napolje! Ne turbiraj drugih' ".50

$\mathrm{Na}$ kraju, danas je sasvim izvesno da je taj odlomak deo nečeg većeg što je nosilo naslov Projectum pro graviminibus et postulatis Rascinae anno $1790 .$. elaboratum.

Muškatirović je kroz ovaj tekst provlačio tvrdnju da su Srbi postojali i igrali političku ulogu u Ugarskoj i pre svojih seoba od XVI veka pa nadalje kao i to da su se oduvek odlikovali u borbama za hrišćanstvo i slobodu Ugarske. Pri radu Muškatirović je koristio od starijih istoričara Antonija Bonfinija, a od mađarskih Turocija, Sentivanija, Ištvanfija, Stefana Kaprinajija, ali i srpskog Pavla Đulinca.

47 Ovde treba reći da je celokupni tekst momoranduma objavljen u Srpskom Sionu za 1905. godinu na str. $421-425,453-460,517-521,569-571,593-596$. No, ovde i napomena. U Srpskom Sionu objavljena je nešto skraćenija verzija dok se proširena nalazi u Rukopisnom odeljenju Matice srpske, M. 11556. Treba napomenuti i da je verzija iz Srpskog Siona objavljena u knjizi Temišvarski sabor 1790, Novi Sad-Sremski Karlovci 1972. str. $155-181$.

48 ,Sva je prilika da je to istorijski deo kakvog graviminalnog projekta, koji su Srbi, prilikom Temišvarskog sabora, podnosili Leopoldu II, dokazujući svoje zasluge u prošlosti i istorijsko pravo na nacionalno samoopredelenje i verske slobode". J. Skerlić. Srpska književnost u XVIII veku, Beograd 1966, str. 383.

49 D. Popović, Srbi u Vojvodini, knjiga treća, Novi Sad 1990, str. 24.

50 D. Popović, Srbi u Vojvodini, knjiga treba, Novi Sad 1990, str. 24 i u Temišrvarski srpski narodni sabor 1790. godine, Arhiv za istoriju Stpske pravoslavne karlovačke mitropolije IV, 1914, 6-50. 


\section{5) Kratka razmišljanja o sredstvima pomoću kojih bi se dragoj našoj otadžbini Madarskoj dobrim mesom $i$ robom moglo postojano pomoći a nestašica mesa, pa i naišla skupoća odstraniti}

Tokom 1802. godine u Budimu izlazi jedna knjiga na mađarskom (veoma kratka) u kojoj Muškatirović raspravlja kako da se Ugarska snabde dobrim i jevtinim mesom, a pod nazivom Kratka razmišljanja o sredstvima pomoću kojih bi se dragoj našoj otadžbini Madarskoj dobrim mesom i robom moglo postojano pomoći a nestašica mesa, pa i naišla skupoća odstraniti.

Nju će Muškatirović kasnije da prevede i na srpski i knjiga će izaći 1805. godine u Budimu. U uvodu se navodi svrha njena: „Poneže svakago dobroga graždanina dužnost je da onoliko koliko obštemu dobru služiti može, ne propusti”. Inače knjiga je posvećena „visokorodnomu gospodinu Joanu Palikučevni ot Furluk, slavnago komitata krašovskago sudejskija stolici sosedatelju, gospodinu zetu mojemu, premilomu i počtenjejšemu". Dakle, knjiga je posvećena Jovanu Palik-Učevni od Furluka, koji je bio Muškatirovićev zet.

Upravo će od Jovana Palikučevna Matica srpska dobiti najveći legat. Jovan, najpre se potpisivao sa Palikuća, a onda, kada je dobio plemstvo, kao Palikučevni, odnosno Palik-Učevni; dobio je plemstvo 1801. godine. Kasnije je od više županija dobio počasni naziv "tablabirova”. Rođen je u Mostaru ili Trstu, najpre živeo u Temišvaru, a onda u Banatu gde je kupio veliko dobro Furluk i Dezest. Prva mu je žena bila Muškatirovićeva ćerka, a druga temišvarskog vladike Putnika.. ${ }^{51}$

\section{i) Na kraju}

Kada se govori o Muškatiroviću mora se reći da se u svakom pogledu radi o veoma kulturnom čoveku, intelektualcu čije se ime veoma često sreće među „,prenumerantima” ondašnjih srpskih knjiga. Kako D. Popović navodi Muškatirović je znao nemački i latinski, a verovatno i mađarski. ${ }^{52}$ Zapravo, mađarski je znao sigurno jer se iz gornjeg teksta vidi da je njegov tekst Kratka razmišljanja... napisao najpre na mađarskom, a onda ga preveo na srpski. Bio je poznat i po tome što je posedovao veliku biblioteku što je tada bila retkost. ${ }^{53}$

Kao advokat uživa priličan ugled tako da ga Aleksije Vezilić u svojoj knjizi Kratkoe napisanie o spokojnoi žizni (Beč, 1788) spominje kao Srbina „koji s perom dobro voziti znajut” i posvećuje mu stihove: str. 836

51 O njemu detaljnije kod Ž. Milisavac, Istorija Matice srpske, I deo, Novi Sad 1986,

52 D. Popović, Srbi u Vojvodini, knjiga druga, Novi Sad 1990, str. 410.

53 Istorija srpskog naroda, četvrta knjiga. drugi tom. Beograd 1994, str. 211. 
Dobrodetelj jest tebe svetu javila

u madarski konzilijum hvalio dovela...

Muškatirovič Jovan v pravah iskusen

mnogimi vjetri pognan ostal nevreżden.

Jako stjena vavilonska stoit nestrjasni

ne boitsja vjetra vsaka on dobrosovjestni.

Pohvaliće ga i Nikola Stamatović stihovima:

Senatora Muškatoroviča

$i$ blagorodnog Novakoviča

Vesme hvalu otečesku

Predprijatija previsoko..$^{54}$

Muškatirović je bio čovek koji je voleo život (kao i većina advokata). Tako je ostalo zabeleženo da je često govorio da bi „dao sve slasti ovog sveta za jednu šunku, koju bi zalivao dobrim fruškogorskim vinom". A upotrebljavao je i „čestvovao" i rakiju. U jednom pismu od 3. 6. 1770. godine on piše igumanu manastira Remete: "Vi kao nov iguman šaljete novu šljivovicu - nadam se inače i staroj".

Muškatirovića i inače ne treba shvatati suviše strogo. On je bio čovek svoga vremena, pun duha, znanja, ambicija i svega onoga što krasi čoveka onoga doba. Možda ga portret koji se danas nalazi u Advokatskoj komori prikazuje suviše strogo. On je objavljen u drugom izdanju njegovih Pričta. Uokolo slike je ispisano „Joan Muškatirovič, senator peštanski”, a ispod je dodano: „Evo Učenik bez knige dosad. Evo knige s Učiteljem odsad". Slika predstavlja simpatičnog, omalenog i dežmekastog starca sa podsečenom sedom kosom, obrijane brade i brkova, sa jakim nosem, blaga i očinska lica sa primetnim podvaljkom. Obučen je u mađarsku atilu sa ćurčetom opšivenim krznom. Na prvi pogled reklo bi se da liči na nekog starinskog veoma imućnog ,počtenarodnog kupca” i velikog ,ljubitelja čtenija”, a ne advokata, senatora i pisca.

Muškatirović je umro u 66. godini života (14. juli 1809. godine) ${ }^{55}$ u Pešti. Sahranjen je 16. jula u groblju kod srpske pravoslavne crkve.

Najstariji sin Jovana Muškatirovića, Petar, završio je prava, a 1. novembra 1796. godine on je u Novom Sadu kao jurat (svršen pravnik, ali bez advokatske diplome). Ispit advokatski polaže 10. septembra 1800. godine, kao „oboi prava vengerski zakl. advokat”. Bio je poznat advokat i družio se sa Lukijanom Mušickim. No, rano je umro, 21. maja 1802. godine (imao 31 godinu). Kao uspomenu na svoga prerano umrloga druga, Mušicki je ispevao Eklogu na preždevremenu o smrti Petra Muškatiroviča (izašla u Budimu 1803. godine). ${ }^{56}$

54 Slaveno-serbskomu rodu i otečestwu so userdiem ot narodolobca posviščeno, Bu. $\operatorname{dim} 1798$, str. 20.

55 Safarik je navodio datum 18. juli 1809. godine.

56 Lukijan Mušicki, Stihotvorenia, knjiga četvrta, Novi Sad 1847, str. 117. 